\title{
Estimation of base grout quantity for cast in situ piles based on field test results
}

\author{
S. K. Bagui $i^{*}$, S. K. Puri ${ }^{2}$, Venkat Rao ${ }^{2}$, B. C. Dinesh ${ }^{2}$ and Atasi Das ${ }^{3}$
}

\author{
* Correspondence: swapanbagui@ \\ gmail.com \\ ${ }^{1}$ CGM, HOD (PMG Division) ICT (I) \\ Pvt. Ltd, New Delhi, India \\ Full list of author information is \\ available at the end of the article
}

\begin{abstract}
Base grout improves the load bearing capacity of a pile and reduces the base settlement. There is no established method presently for the determination of quantity of the base grout. This paper presents a model for the determination of quantity of the base grout and verification of actual quantity executed during the base grouting operation in the field. The depth of the sediment deposit at the bottom of the pile has been observed to vary in the range of $0.3 \mathrm{~m}$ to $0.8 \mathrm{~m}$ or more for the case study presented. This depth of sediment deposit also depends on the pile drilling method adopted. In this model, it is assumed that maximum depth of deposition of $0.3 \mathrm{~m}$ may be allowed for concrete work. Based on the available literature and a Guideline on Pile Construction of Hong Kong, bottom cleaning is required if the depth of deposition is more than $0.3 \mathrm{~m}$. Grout quantity also depends on the diameter and, length of a pile, and number of piles, as well as length and diameter of Tube A Manchette (TAM) Tubes and depth of deposition of sediment which takes place before concrete work execution. A case study has been adopted. Theoretical model has been developed based on the quantity executed during base grouting in field. Actual quantity of base grout shall be more than theoretical quantity due to the possible caving in of the side walls of the piles, increased diameter in the bottom of pile tip with the formation of a bulb at times. Therefore, a variable coefficient ' $K$ ' has been presumed equating theoretical quantity to actual quantity including loss of base grout quantity. ' $K$ ' value has been determined at 95\% reliability and found to be 1.22 . The proposed model for quantity estimation of base grout has also been validated with other field data and the results have been found to be satisfactory.
\end{abstract}

Keywords: Base grout, Shaft grout, TAM, Base grout quantity

\section{Introduction}

In early 1960, efforts to improve the end bearing of drilled shafts began in Europe using high pressure grout injected beneath the shaft tip for a cast in situ pile (Bolognesi and Moretto 1973; Gouvenot and Gabiax 1975; Stocker 1983).

Thereafter, numerous case studies have been documented stating its effectiveness after various site implementations. This end bearing modification technique, also called tip post-grouting or base grouting has been used worldwide; yet literature on its use lacks a rational design approach. As a consequence, there has been little use in the

(c) The Author(s). 2020 Open Access This article is licensed under a Creative Commons Attribution 4.0 International License, which permits use, sharing, adaptation, distribution and reproduction in any medium or format, as long as you give appropriate credit to the original author(s) and the source, provide a link to the Creative Commons licence, and indicate if changes were made. The images or other third party material in this article are included in the article's Creative Commons licence, unless indicated otherwise in a credit line to the material. If material is not included in the article's Creative Commons licence and your intended use is not permitted by statutory regulation or exceeds the permitted use, you will need to obtain permission directly from the copyright holder. To view a copy of this licence, visit http://creativecommons.org/licenses/by/4.0/. 
United States. A thorough overview of post-grouting processes can be found elsewhere (Mullins et al. 2001).

Six years of research work on base grouting conducted at the University of South Florida, on behalf of the Florida Department of Transportation, has produced a reliable methodology for predicting the end bearing of base grouted shafts (Mullins et al. 2006). Since then, many projects, both public transportation and private sector, have utilized base grouting with great success, and have further verified the design methodology.

Post-construction base grouting (or tip grouting) of deep foundation elements, typically drilled shafts (bored piles) are becoming popular in the Unites States and also slowly gaining attention and importance in the other parts of the world where the soil is vulnerable. There is limited direct comparison between grouted and un-grouted shaft performance available in the literature (Dapp et al. 2006).

In general, the post-grouting technique involves casting drilled shafts with a grout delivery system along with the TAM (Tube A Manchette) incorporated into the pre-fabricated reinforcing cage capable of placing high pressure grout at the base of the shaft after the shaft concrete has cured. This densifies the in situ soils and compresses any debris left by the drilling process obtained from pile load deflection results. Moreover, by preloading the soil beneath the tip, end bearing capacity can be developed within service/displacement limits. It was suggested that pressure-grouted shafts tipped in loose to medium dense sand provided the maximum benefit, but improvement was observed in all soil types. Specifically, end bearing could be improved in sands and clays with ultimate capacities as much as two to three times conventional un-grouted shafts. The same sources supported end bearing improvement to be dependent on the volume of grout injected. However, the improvement was shown to be more directly related to grout pressure and forms the basis of the new design method. During base grouting, the grout pressure produces a bi-directional force at the shaft tip, wherein the development of the end bearing is resisted by the skin friction of the shaft. Hence, longer shafts or shafts that develop more side shear can resist higher grout pressure. The maximum grout pressure is dependent on the available side shear on which the grout pressure can react (Bruce 1986).

\section{Geotechnical condition for base grouting}

Geotechnical investigation is most important aspect for finalization of requirement of base grouting for piling works. Following points are to be considered for execution of base grouting (Evans et al. 1982):

1. The most significant end bearing capacity enhancement from base grouting is realized in cohesion less soils for pile tip resting on cohesion less soil i.e., silty sand along the pile length partially / fully;

2. Base grouting in cohesive soils below toe, while resulting in much less improvement in end bearing capacity;

3. If a rock-bearing stratum exists at relatively shallow depth, base grouting provides limited benefit; the grout pressure provides no improvement of the native bearing materials and the shallow depth limits the magnitude of the base pressure that can be achieved due to the limited uplift resistance of the shaft; and 
4. Deep shafts in rock can provide benefit in verifying that the end bearing resistance is achieved where, there may be difficulty in achieving a thorough cleaning of the rock bearing surface, or where the rock can include layers.

\section{Base softening}

It was observed (Evans et al. 1982) that significant softening of a pile base is encountered down to a depth of $0.8 \mathrm{~m}$. The degree of softening increased with the duration of time between completion of excavation and commencement of concreting. It was further observed that upon concreting, re-compression of the softened base took place to a depth of about $50 \%$ of the pile diameter over a period of 10 days. Grouting of the pile base was carried out at a maximum pressure of $3 \mathrm{MPa}$ but the re-compression of the softened material was not significant in this instance. If there are lengthy delays to the placement of reinforcement and concrete, consideration may be given to constructing a concrete plug at the bottom of the pile in order to limit the effects of stress relief.

Similar findings of base softening (Endicott 1980) were reported from loading tests on short length concrete plugs that the base stiffness was satisfactory, with the load resisted by shaft resistance. However, to improve confidence level and alleviate the concern of long-term behaviour of foundation with a soft base, the pile base was grouted to achieve a given probe test resistance.

Fifty two piles with $2.5 \mathrm{~m}$ diameter were constructed during construction of an extra dosed cable stayed Bridge across river Paira in Bangladesh with varying length of pile from $110 \mathrm{~m}$ to $130 \mathrm{~m}$ and sediment depositions were measured before reinforced cage installation as well as during reinforced cage installation prior to concreting. It is found that depth of deposition generally varied from $300 \mathrm{~mm}$ to $900 \mathrm{~mm}$. Cleaning of base is considered where the deposition is more than $300 \mathrm{~mm}$. Reverse circulation method is used for bottom cleaning. Average $300 \mathrm{~mm}$ deposition is adopted for base grouting quantity estimation model. Development of model is presented here in.

\section{Literature review}

Yueqing Bay Bridge test pile program was located in Zhejiang Province, China. A pile was constructed in the field using base grouting to improve the bearing capacity and decrease the settlement of the pile. Length and diameter of the pile were $88 \mathrm{~m}$ and 2 $\mathrm{m}$. The base grouted pile compared to non-grouted pile is believed to be relatively stronger than the side friction reinforcing effect, which is due to the grout penetration upward along the sides of the pile. Base grout enlarges tip diameter and pre-compresses the soil under the pile tip, and results in tip resistance and stiffness improvements of piles due to tip pressure grouting. The bearing capacity of post grouted pile was analyzed by a single factor, which showed that the single factor was not sufficient to predict the load settlement curve of post grouted pile. Considering the combined influence of these three factors, the prediction of the load settlement curve was consistent with the measured curve. The results indicate that the effect of post grouted pile was improved by these three factors (Zhihui et al. 2016).

Base grouting is becoming widely popular in the drilled shaft industry as a means to improve shaft response to load and minimise the possible settlement due to the construction defects, if any. This paper presents several case histories of full-scale static load tests conducted on adjacent shafts with and without base grouting on projects in 
various parts of the United States. All tests were performed using Osterberg cell (Ocell) test method. The comparisons yielded some intriguing results. In some cases, the results matched theory quite well and showed improvement in the overall pile capacity. These case histories concluded for further load testing and research to better understand how drilled shaft capacity is affected by base grouting, particularly, how the capacity is affected by drilling, base cleaning, and base grouting techniques and quality control in various soil materials (Sinnreich and Simpson 2015).

The load transfer characteristics and mobilization of skin friction and, tip bearing resistance were determined from the strain gauge results. The test results of the base grouted bored pile was compared with the results of two conventional slurry stabilized bored piles and a barrette installed in similar ground conditions. Substantial increase in pile toe stiffness and skin friction resistance was found for the grouted pile. Analysis of the results suggests that, in addition to improvement of the pile toe bearing condition, it was possible for grout to flow upwards along the pile shaft-soil interface during grouting at very high pressures, thereby enhancing the skin friction resistance as well (Chu 2012).

Grouted piles are used to reinforce base soil to increase the base stability of excavations in soft clay and to reduce excavation-induced ground movements. To propose a model for the base undrained stability of deep excavation in clay reinforced with grout piles, this paper presents an anisotropic strength criterion for clay reinforced with grout piles and the upper-bound bearing capacity theory for excavation. The proposed model is capable of determining the factor of safety against base heave for an excavation with or without ground improvement for various-strength anisotropy ratios of clay and clay reinforced with grout piles. The suitability of the model is verified with five field excavation cases. However, the factor of safety becomes insensitive to the undrained shear strength of a grout pile when the improvement ratio is less than $10 \%$. Results from the model found that the increment of factor of safety against base heave and the increment of improvement ratio is generally $1: 2$. Finally, it can be used only in excavations with the width and depth of ground improvement zone larger than 1.41Dp and 1Dp (Dp is depth of the retaining wall minus depth of excavation), respectively (Liao and $\mathrm{Su} 2012$ ).

The foundation pit of Zhongsheng Commercial Centre Building was constructed using top-down method. The one-pile-supporting-on-column mode was adopted in the foundation excavation and basement construction, which means a higher capacity of piles to sustain the total load imposed by the building structure and the temporary constructing loads. Base grouting technique was used improve the bearing capacity of the conventional bored piles that are usually constructed using bentonite slurry. In order to verify the effectiveness of base grouting, static load tests were conducted on three base grouted piles and three conventional bored piles, those of $48 \mathrm{~m}$ long and embedded into sand. Finally the skin friction, base grouting significantly improved the overall performance of the pile with base grout (Wang et al. 2006).

Grouting at the bottom of a pile may considerably increase the bearing capacity, reduce settlement, and improve the property of pile-soil working together, hence its wide application in recent years in China. This paper explains the mechanism of how grouting improves the bearing capacity, the technical parameters of grouting, quality guarantee measures and common problems in grouting. It is found that base grouting is not 
only active, but also economical and simple, therefore it is a worthwhile technology to consider (Zhang et al. 2004).

An O-Cell load test conducted for the Pakhsey Bridge over the Padma (Ganges) River in western Bangladesh. The test program consisted of the installation and testing of two $1.5-\mathrm{m}$ diameter bored piles to depths of $65 \mathrm{~m}$ and $91 \mathrm{~m}$. The paper discusses the design of the high capacity bored piles for a site susceptible to deep scour. The paper also discusses the installation of the test piles, and the application of base-grouting to improve end bearing resistance. Finally, the paper documents and evaluates the results of Osterberg load tests at the two test piles, including a comparison of pile capacity before and after base grouting.

\section{Summary of literature review}

Base grout increases the tip area of the pile due to the formation of grout bulb, which pre-compresses the soil under the pile tip, and results in tip resistance and stiffness improvements of piles due to tip pressure grouting.

- Base grout improves pile capacity and reduces pile settlement.

- A review of base grouting records for 32 working piles indicated that there was an approximate correlation between cement consumption, the number of grouting stages and the volume of pile shaft.

- Base grout improves skin friction near the toe and this occurred due to the upward movement of base grout.

Based on literature review, it is found that no model is available to estimate the quantity of grout required during base grouting at site. Therefore, there is a need of study to estimate base grout quantity and develop a model.

\section{Geotechnical investigation of pile}

Geotechnical investigation was carried for depth varying from $125 \mathrm{~m}$ to $140 \mathrm{~m}$ and soil profile is presented in Table 1.

Table 1 Soil Profile of the Pile

\begin{tabular}{lllll}
\hline Depth $\left(Z_{s}\right)$ & $\begin{array}{l}\text { Submerged unit } \\
\text { wt. }(\gamma)\end{array}$ & Cohesion(C) & $\begin{array}{l}\text { Angle of internal } \\
\text { friction }(\varnothing)\end{array}$ & Soil Strata \\
\hline $\mathrm{m}$ & $\mathrm{KN} / \mathrm{m}^{3}$ & $\left(\mathrm{KN} / \mathrm{m}^{2}\right)$ & Degree & \\
0 to 46.5 & 9.0 & 5 & 10 & Soft mixed soil \\
46.5 to 49.5 & 9.0 & 0 & 30 & Non Plastic Grey silty Sand \\
49.5 to 58.5 & 9.0 & 20 & 24 & Mixed soil of dark clay with silt, sand \\
58.5 to 63 & 9.0 & 30 & 0 & Brownish grey stiff clay \\
63 to 76.5 & 9.0 & 31 & 0 & Non Plastic Light brown silty sand \\
76.5 to 85.5 & 9.0 & 30 & 10 & Mixed soil of Grey sandy silt with \\
85.5 to 99 & 9.0 & 0 & trace clay \\
99 to 108 & 10 & 0 & Stiff grey clay silt with trace clay \\
108 to 123 & 4 & 10 & 30 & Non Plastic Grey silty fine sand \\
123.0 to 140 & 3 & 0 & 36 & Mixed clayey silt and sandy silt \\
\hline
\end{tabular}


For saturated soil, the Chinese Building Code(2008) prescribes a water-to-cement ratio of 0.45 to 0.65 . For unsaturated soil, the water-to-cement ratio should be 0.7 to 0.9 , while for "loose soil aggregate and grit," the water-to-cement ratio should be 0.5 to 0.6 .

The code also defines maximum pressures to be used depends on the classification of the stratum to be post-grouted. For disintegrated rock, unsaturated "cohesive soil and silty soil," the code prescribes a grouting pressure of 3 to $10 \mathrm{MPa}$; while for saturated soils, the pressure should be 1.2 to $4 \mathrm{MPa}$, with the lower range of values adopted for "soft soils" and the higher range for "dense soils." The code also dictates that the maximum grout flow is $75 \mathrm{~L} / \mathrm{min}$ and that the target grout volume must be calculated using shaft length, diameter, soil properties.

There is also a distinction made between individual shafts and those clustered in groups, with the calculated volume multiplied by a value of 1.2 .

Grouting depends on the conductivity of the material and efficiency of grouting for filling as mentioned in Table 2.

Permeabilty of rock depends on the rock type, joints and fractures with permeability as mentioned in Table 2 as mentioned above.

Higher grout pressure can be applied where dense soil and lower grout pressure may be applied where medium and loose soil is available. Grouting time can be increased for the loose and medium soil/ fractured rock and time period may be decreased for the case of dense / intact rock.

Thinner mix i.e., high consistency of grout (More w/c ratio) is required for the low grout pressure and high consistency of grout is required for the case of high pressure. Therefore, consumption of grout depends on grout pressure and consistency of grout. This data was not collected during field carrying base grout.

\section{Model for calculation of quantity of base grouting}

A typical model is presented here (Fig. 1). Let Lp and Dp be the length and diameter of pile. Length, diameter and number of grout pipe are Lg, Dg and Ng respectively. Depth of deposition at the bottom of the soil is dd. Assuming $\mathrm{dg}_{1}, \mathrm{dg}_{2}$ and $\mathrm{dg}_{3}$ are the depth of grout at the bottom of pile for Stage1, Stage 2 and Stage 3 grouting, respectively.dd is the actual deposition of sediment observed just before concreting work.

Volume of deposition $=(\pi / 4) \times \mathrm{Dp}^{2} \times \mathrm{dd}$

Where dd is actual depth of deposition before concreting.

There is always chance of enlargement of bottom of the pile due to high pressure grouting. Hence, actual bottom diameter of pile may be more than design diameter Dp. It is assumed actual grout volume will be more than that of basic quantity.

Grout is also required in grout pipes.

Table 2 Grout Efficiency

\begin{tabular}{lll}
\hline Soil Type Description & Permebility $(\mathrm{m} / \mathrm{s})$ & Grout Filling Condition for $\mathrm{f}=$ Filling Efficiency $>90 \%$ \\
\hline Silty Sand & $>10^{-7}$ & Fair Grouting \\
Dense fine sand,silty sand & $10^{-7}$ to $10^{-8}$ & Difficult Grouting \\
Clayey Silt & $<10^{-8}$ & Very Difficult Grouting \\
\hline
\end{tabular}




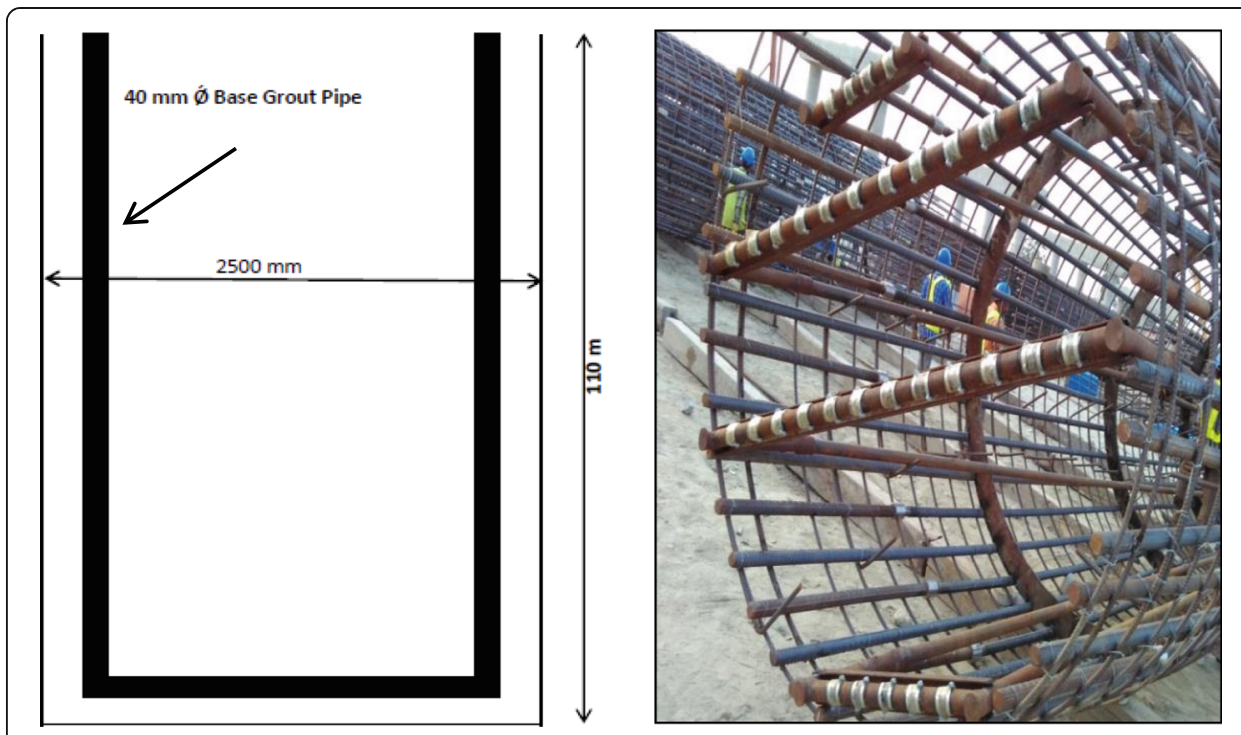

Fig. 1 Bottom Plan and Elevation of Base Grouting Arrangement for $110 \mathrm{~m}$ Long Pile with Tube a Manchette (TAM)

Quantity in grout pipes $=(\pi / 4) \times \mathrm{Dg}^{2} \times(\mathrm{NgLg}+2.4 \mathrm{Dp})$

Total quantity for Stage $1=(\pi / 4) \times \mathrm{Dg}^{2} \times \mathrm{dg} 1+(\pi / 4) \times \mathrm{Dg}^{2}$

$$
\times(\mathrm{LgNg}+2.4 \mathrm{Dp})
$$

Four pair of base grout pipes were used as shown in Fig. 1 and pipes are bent at the toe with the bottom bent lengths being $0.4 \mathrm{D}, 0.8 \mathrm{D}, 0.8 \mathrm{D}$ and $0.4 \mathrm{D}$ i.e., total $2.4 \mathrm{D}$ is found for placement of grout on the bottom as shown in Fig. 1. It may be varied depending on the arrangements of grout pipes.

Assuming the various factors involving loss due to Grout machine, enlargement of base due to high grout pressure, removing loosening bottom soil due to initial water pressure and cleaning of TAM Pipe for second stage grouting and cracking after $12 \mathrm{~h}$ of first stage grouting, total quantity of base grout is determined using following Equations:

Final Stage 1

Volume of grout $\left.\left.=[\pi / 4) \times \mathrm{Dg}^{2} \times \mathrm{dg} 1\right)+(\pi / 4) \times \mathrm{Dg}^{2} \times(\mathrm{NgLg}+2.4 \mathrm{Dp})\right]$

Similarly, volume of grout for Stage 2 is given by:

Final Stage 2

Final Volume of grout $=\left[(\pi / 4) \times \mathrm{Dg}^{2} \times \mathrm{dg} 2+(\pi / 4) \times \mathrm{Dg}^{2} \times(\mathrm{NgLg}+2.4 \mathrm{Dp})\right]$

Therefore, Final Total Volume of grout is obtained by summing up Eq. 4 and Eq. 5:

$$
\text { Total Grout Volume }=\left[(\pi / 4) \times \operatorname{Dg}^{2} \times(\mathrm{dg} 1+\mathrm{dg} 2)+2 \times(\pi / 4) \times \mathrm{Dg}^{2} \times(\mathrm{NgLg}+2.4 \mathrm{Dp})\right]
$$

Let dga is the actual depth of deposition as mentioned in Table 1 for each pile. Therefore, actual grout requirement for the case of total volume of deposition will be replaced by total volume deposition plus volume of grout occupied by grouting pipe. This will be determined using following Equation: 
Final Volume of Grout $=\mathrm{k} \times\left[(\pi / 4) \times \mathrm{Dg}^{2} \times \mathrm{dga}+2 \times(\pi / 4) \times \mathrm{Dg}^{2} \times(\mathrm{NgLg}+2.4 \mathrm{Dp})\right]$

Unknown factor $\mathrm{k}$ will be determined from field executed quantity of base grout and theoretical quantity of base grout equating Eq. 6 yields same value as mentioned in Eq.7 i.e., value of Eq. 6 is equal to value of Eq. 7. Eq. 7 is the basic Equation for estimation quantity of base grout for execution and estimation of quantity in the feasibility stage assuming some practical value of dga (Depth of sediment deposition) in the range of $500 \mathrm{~mm}$.

The model adopted for quantity estimation of base grouting is shown in Fig. 1 represented as elevation and in the bottom plan. Length of base grouting pipe is taken as $110 \mathrm{~m}$ for grout quantity estimation. Total eight pipes are proposed for base grouting.

Deposition was measured during construction of pile. One pile construction took seven (7) days from the time of excavation of pile to finishing the concreting work. Deposition of sediment was measured using wire rope with weight as shown in Fig. 2. Initial depth of boring hole of the pile was measured after excavation and cleaning when density of water with bentonite slurry was around $1.1 \mathrm{~g} / \mathrm{cc}$. Second measurement was taken after installation of reinforcement caging. If the variation of depth was measured as less than the range of $300-400 \mathrm{~mm}$ from initial measurement i.e., the depth of deposition, pouring of concreting was continued, otherwise washing / bottom cleaning was carried out and again measuring the deposition to fall below $400 \mathrm{~mm}$.

\section{Field data analysis}

Twelve piles are constructed with following pile properties:

- Length of pile: $110 \mathrm{~m}$

- Diameter of pile:2.5 m

- Base grout Concrete: Class C 20 (28 days $10 \mathrm{~cm}$ cube Strength $20 \mathrm{MPa}$, water Cement Ratio 0.6 used)

Actual base grout has been conducted in two stages and summarized quantities executed during execution of base grout presented in Table 3.

Washing of bore hole was carried out after completing the bore hole using fresh bentonite slurry and depth of the bore hole measured and same procedure repeated just

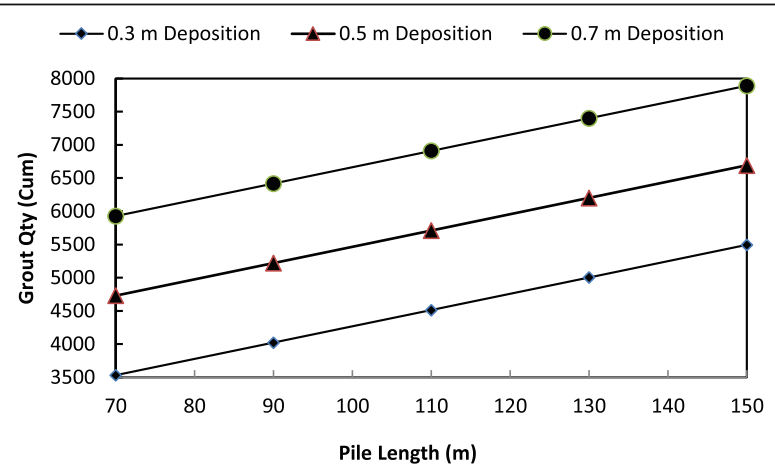

Fig. 2 Variation of Base Grout Quantity Varying Length and Deposition for 2.5 m diameter pile 
Table 3 Quantity of Base Grout in Two Stages

\begin{tabular}{|c|c|c|c|c|c|c|}
\hline \multirow[t]{2}{*}{ Pier } & \multirow{2}{*}{$\begin{array}{l}\text { Pile } \\
\text { Description }\end{array}$} & \multicolumn{3}{|c|}{ Grout Quantity (Litres) } & \multirow{2}{*}{$\begin{array}{l}\text { Stage } 2 \\
\text { Holding } \\
\text { Pressure } \\
(\mathrm{MPa})\end{array}$} & \multirow{2}{*}{$\begin{array}{l}\text { Depth of } \\
\text { Deposition } \\
\text { before } \\
\text { Concreting } \\
(\mathrm{mm})\end{array}$} \\
\hline & & Stage 1 & Stage 2 & Total & & \\
\hline \multirow[t]{6}{*}{$P 16$} & P 1 & 3162.5 & 2172.5 & 5335 & 3.3 & 422 \\
\hline & P 2 & 3116.6 & 2273.4 & 5390 & 4.5 & 448 \\
\hline & P 3 & 3117.5 & 2577.5 & 5695 & 5 & 465 \\
\hline & P 4 & 3120.5 & 2170.5 & 5291 & 3.1 & 461 \\
\hline & P 5 & 3117.5 & 2172.5 & 5290 & 4.0 & 484 \\
\hline & P 6 & 3100 & 2173.5 & 5273.5 & 3.2 & 467 \\
\hline \multirow[t]{6}{*}{ P20 } & P 1 & 3114.6 & 2272.4 & 5387 & 4.5 & 500 \\
\hline & P 2 & 3167.5 & 2178.5 & 5346 & 3.6 & 492 \\
\hline & P 3 & 3115.5 & 2477.5 & 5593 & 5 & 508 \\
\hline & P 4 & 3127.5 & 2175.5 & 5303 & 4.3 & 488 \\
\hline & P 5 & 3135.5 & 2175.5 & 5311 & 3.2 & 565 \\
\hline & P 6 & 3110 & 2183 & 5293 & 3.5 & 497 \\
\hline
\end{tabular}

before concreting work if depth measured was found to exceed $600 \mathrm{~mm}$, followed by bottom cleaning before concreting. The difference is the depth of sedimentation. More or less, similar difference is observed in the Grouting pipe.

Based on actual grout used in Stage 1 and Stage 2, the results are shown in Table 4 and Equivalent grout thicknesses are determined and presented in Table 4 using Eq. 6.

$\mathrm{K}$ factor as mentioned in Eq. 6 has been determined based on Eq. 6 and 7 and presented in Table 5 .

$\mathrm{K}$ value has been determined at $95 \%$ reliability and found to be close to 1.22 . Taking $\mathrm{k}$ value of 1.22, final quantity of base grout is estimated using following Eq. 8:

Total Grout Volume $=1.22 \times\left[(\pi / 4) \times \mathrm{Dg}^{2} \times \mathrm{dga}+2 \times(\pi / 4) \times \mathrm{Dg}^{2} \times(\mathrm{NgLg}+2.4 \mathrm{Dp})\right]$

Table 4 Equivalent Grout Depth

\begin{tabular}{|c|c|c|c|c|}
\hline \multirow[t]{2}{*}{$\overline{\text { Pier }}$} & \multirow{2}{*}{$\begin{array}{l}\text { Pile } \\
\text { Description }\end{array}$} & \multicolumn{3}{|c|}{ Equivalent Grout Depth (mm) } \\
\hline & & $\overline{\text { Stage } 1}$ & Stage 2 & Total \\
\hline \multirow[t]{6}{*}{$\overline{\mathrm{P}} 16$} & P 1 & 396 & 194 & 590 \\
\hline & P 2 & 386 & 215 & 601 \\
\hline & P 3 & 386 & 276 & 663 \\
\hline & P 4 & 387 & 194 & 581 \\
\hline & P 5 & 386 & 194 & 580 \\
\hline & P 6 & 383 & 194 & 577 \\
\hline \multirow[t]{6}{*}{ P20 } & P 1 & 386 & 214 & 600 \\
\hline & P 2 & 397 & 195 & 592 \\
\hline & P 3 & 386 & 256 & 642 \\
\hline & P 4 & 389 & 195 & 583 \\
\hline & P 5 & 390 & 195 & 585 \\
\hline & P 6 & 385 & 196 & 581 \\
\hline
\end{tabular}


Table 5 Value of $\mathrm{K}$

\begin{tabular}{|c|c|c|c|c|c|c|c|}
\hline \multirow[t]{2}{*}{ Pier } & \multirow{2}{*}{$\begin{array}{l}\text { Pile } \\
\text { Description }\end{array}$} & \multicolumn{3}{|c|}{ Grout Quantity (Litres) } & \multirow{2}{*}{$\begin{array}{l}\text { Depth of } \\
\text { Deposition } \\
\text { before } \\
\text { Concreting } \\
(\mathrm{mm})\end{array}$} & \multirow{2}{*}{$\begin{array}{l}\text { Quantity } \\
\text { based } \\
\text { actual } \\
\text { Sediment } \\
\text { Deposition } \\
\text { (Litres) }\end{array}$} & \multirow[t]{2}{*}{ K } \\
\hline & & Stage 1 & Stage 2 & Total & & & \\
\hline \multirow[t]{6}{*}{ P 16} & P 1 & 3162.5 & 2172.5 & 5335.0 & 422.0 & 4512.8 & 1.18 \\
\hline & P 2 & 3116.6 & 2273.4 & 5390.0 & 448.0 & 4652.8 & 1.16 \\
\hline & P 3 & 3117.5 & 2577.5 & 5695.0 & 465.0 & 4744.4 & 1.20 \\
\hline & P 4 & 3120.5 & 2170.5 & 5291.0 & 461.0 & 4722.9 & 1.12 \\
\hline & P 5 & 3117.5 & 2172.5 & 5290.0 & 484.0 & 4846.7 & 1.09 \\
\hline & P 6 & 3100.0 & 2173.5 & 5273.5 & 467.0 & 4755.2 & 1.11 \\
\hline \multirow[t]{6}{*}{ P20 } & P 1 & 3114.6 & 2272.4 & 5387.0 & 500.0 & 4932.9 & 1.09 \\
\hline & P 2 & 3167.5 & 2178.5 & 5346.0 & 492.0 & 4889.8 & 1.09 \\
\hline & P 3 & 3115.5 & 2477.5 & 5593.0 & 508.0 & 4976.0 & 1.12 \\
\hline & P 4 & 3127.5 & 2175.5 & 5303.0 & 488.0 & 4868.3 & 1.09 \\
\hline & P 5 & 3135.5 & 2175.5 & 5311.0 & 565.0 & 5283.0 & 1.01 \\
\hline & P 6 & 3110.0 & 2183.0 & 5293.0 & 497.0 & 4916.8 & 1.08 \\
\hline
\end{tabular}

Base grout quantity has been determined using Eq. 8 by varying length of pile and sediment deposition thickness and presented graphically in Fig. 2 for pile diameter of $2.5 \mathrm{~m}$.

Sediment deposition and diameter of the pile are varied for pile length of $110 \mathrm{~m}$ (Fig. 3). It is also found that all graphs are linear with positive slope. Similar graphs can be prepared for other length of piles.

A graph has also been prepared considering depth of sediment deposition is $500 \mathrm{~mm}$ and varying length of pile and diameter of pile (Fig. 4).

Base grout was prepared with different water cement ratios (W/C) in the laboratory and model test was conducted in the laboratory for checking water cracking. W/C varied from 0.5 to 0.7 . After laboratory cube testing and model testing of base grout, W/C of 0.6 was finalised. Some Photographs shown are included in Fig. 5. Grouting pressure was checked during grouting. When grout pressure was found as 2.5-3.0 MPa and constant for 5-10 $\mathrm{min}$, grouting process was terminated as stage 1 grout quantity consumed.

During finalising grout mix design, model test was also conducted in the site laboratory quantity cement and water required per $\mathrm{m}^{3}$ of grout used presented in Table 6 and Water cement Vs Grout pressure observed and shown in Fig. 6.

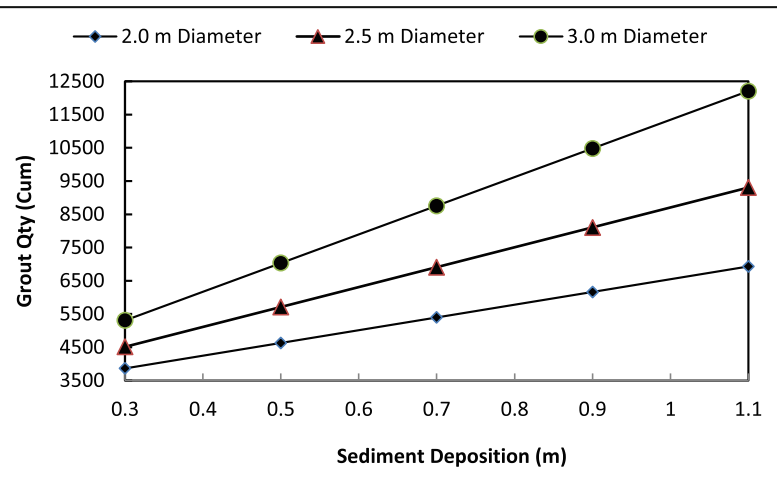

Fig. 3 Variation of Base grout Quantity with Varying deposition and diameter of Pile vs for $110 \mathrm{~m}$ long pile 


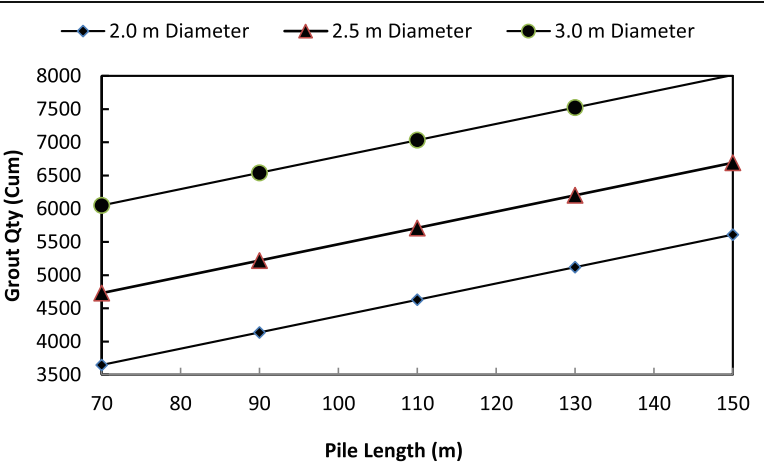

Fig. 4 Variation of Base grout quantity with Varying Pile Diameter and Pile length of pile or sediment deposition of $500 \mathrm{~mm}$

Grout pressure is typically monitored using a Bourdon-type (analog) pressure gauge located near the grout pump. Pressure measurements from these gauges are monitored and manually recorded at frequent time intervals throughout the grouting process. These analog measurements are often supplemented with automated readings from a digital pressure transducer also located near the grout pump. Figure 5 shows a typical combination of a Bourdon gauge attached at the grout pump.

A simple "field check" of the Bourdon gauge is generally performed prior to grouting by filling the grout line with water, capping or "dead-heading" the line, and applying a nominal pressure. Readings from the Bourdon gauge and pressure transducer are compared to establish that both measurements are practically consistent. As is often the case when making similar measurements using different devices, it is common to have small discrepancies between pressures measured using the Bourdon gauge and pressure

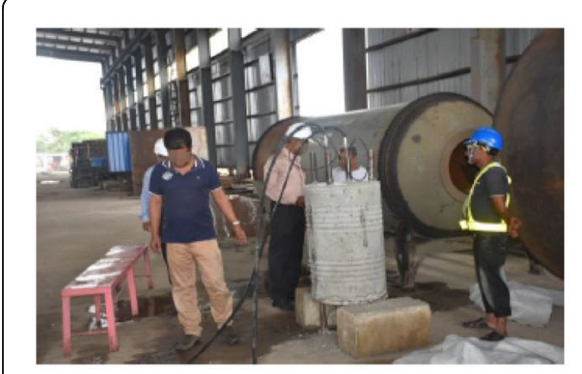

A Grout Simulation at Laboratory

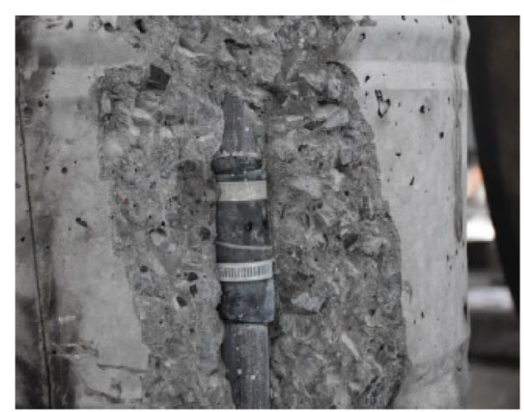

C Base Grout in Progress

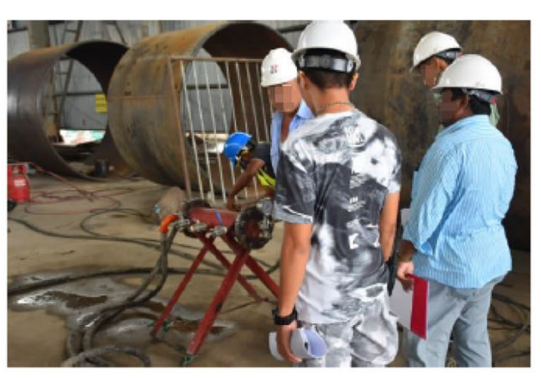

B-Base Grouting Arrangement

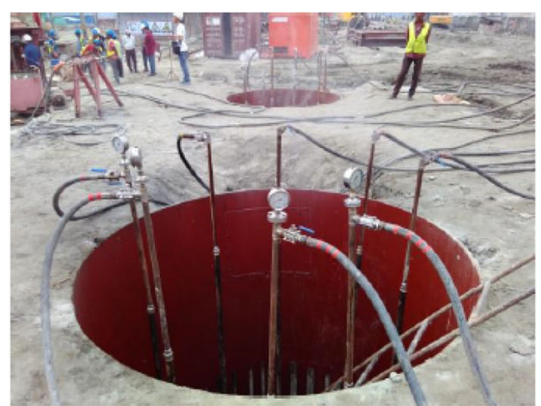

B-Checking Water Cracking prior to Base Grouting

Fig. 5 Some Typical Photographs of Base Grout 
Table 6 Quantity of Ingredient Per $\mathrm{m}^{3}$ Grout

\begin{tabular}{lll}
\hline W/C Ratio & Cement $(\mathrm{Kg})$ & Water(Liter $)$ \\
\hline & 1120.5 & 644.3 \\
0.6 & 1090 & 654 \\
0.625 & 1061 & 663.2 \\
\hline
\end{tabular}

transducer. The alternative readings can generally be considered consistent if the readings fall within a few percent of the range of the gauges. Pressures measured at various positions across the system (e.g., at pump, top of shaft, etc.) should also be expected to differ because of variance in elevation and/or pressure losses along the grout tubes and hoses. However, pressures measured at different positions should be consistent considering relative elevation and expected pressure losses in the hoses/lines. Trends in pressure measured at different positions should also be consistent.

One component of grouting termination criteria that guides and controls grouting operations in the field is a grout pressure. The magnitude of the grout pressure threshold varies substantially from project to project, but typically ranges between $0.67 \mathrm{Mpa}$ and $5 \mathrm{MPa}$. The grout pressure threshold is generally established based on consideration of the grout pressure needed to achieve the desired drilled shaft performance as well as consideration of the grout pressure that can likely be achieved in the field.

Grout pressure will rise steadily in rough proportion to the grout volume delivered, with a simultaneously proportional upward shaft displacement. Such a response indicates that grouting is proceeding as anticipated and should be continued. For example, observation of rapidly increasing grout pressure with little increase in volume delivered and little shaft uplift serves as an indication that the grout supply line(s) have become blocked.

A more common occurrence is to observe an increase in the volume delivered without a proportionate increase in grout pressure. Such observations provide indication of several potential conditions:

The mobilized side resistance that is providing reaction to the upward force on the shaft due to the measured grout pressure is approaching the ultimate side resistance, which results in non-linear upward displacement of the shaft and increasing volume at the shaft tip with little or no increase in the grout pressure.

The mobilized tip resistance at the tip of the shaft is approaching the ultimate tip resistance, which results in non-linear downward displacement of the soil/rock beneath the shaft tip and increasing volume at the shaft tip with little or no increase in pressure.

The grout pressure imposed at the shaft tip has resulted in hydro fracture of the ground around the shaft tip, which provides additional space for grout to flow with little or no increase in pressure. Therefore, Model will affect abnormal situation.

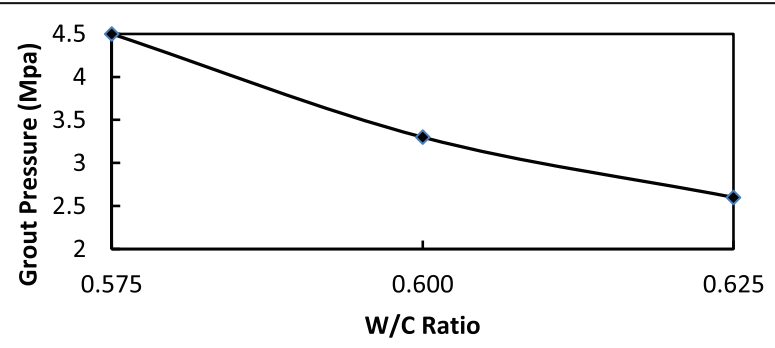

Fig. 6 W/C Vs Grout Presure 


\section{Validation of proposed model}

The proposed model has also been validated using field data of 10 piles of diameter $2.5 \mathrm{~m}$ and $130 \mathrm{~m}$ long with 8 grout pipes of $40 \mathrm{~mm}$ diameter (Table 7).

Average quantity consumed is equal to 57301 (with coefficient of variation of 0.016) whereas average theoretical quantity is found to be $5771 \mathrm{l}$. Variation of grout quantity using proposed model is within $\pm 5 \%$. Coefficient variation is $0.048<0.25$. Therefore, it may be concluded that model is statistical significance and validated. Thus, it may be used for similar condition for other projects.

\section{Discussion}

An analytical method has been developed to determine base grout quantity required for bore cast in situ pile and compared with actual quantity consumed during pile base grouting work. Basic Equ. of base grout quantity depends on following variables as obtained from Eq. 7.

- Diameter of pile

- Diameter of base grout pipe

- Length of pile

- Depth of Sediment

- Number of base grout pipes

Generally, for uniform spread of grout, eight grout pipes are recommended.

Diameter of base grout pipes varied from $20 \mathrm{~mm}$ to $40 \mathrm{~mm}$ and diameter pipe is adopted for base grouting for Paira Bridge Construction Project in Bangladesh.

Quantity of grout has been calculated considering different variables and presented graphically (Fig. 2 and Fig. 4).

Base grout quantity has been determined varying length of pile and deposition sediment thickness and presented graphically for pile diameter of $2.5 \mathrm{~m}$ (Fig. 2). It is observed that quantity of base grout increases linearly with positive slope (Fig. 2). Similar graph can be drawn for other diameters of piles.

Base grout quantity has been determined varying diameter of pile and deposition sediment thickness for $110 \mathrm{~m}$ long pile and presented graphically (Fig. 3). It is observed

Table 7 Validation of Proposed Model

\begin{tabular}{lllll}
\hline Pile & $\begin{array}{l}\text { Actual Base Grout Quantity } \\
\text { Executed (Liter) }\end{array}$ & $\begin{array}{l}\text { Actual Depth of } \\
\text { Deposition }(\mathrm{mm})\end{array}$ & $\begin{array}{l}\text { Quantity from Proposed } \\
\text { Model (Liter) }\end{array}$ & $\begin{array}{l}\text { Variation from Actual } \\
\text { Quantity (\%) }\end{array}$ \\
\hline P21 & 5695 & 411 & 5719 & $0.42 \%$ \\
P22 & 5717 & 420 & 5773 & $0.97 \%$ \\
P23 & 5689 & 400 & 5653 & $-0.64 \%$ \\
P24 & 5688 & 410 & 5713 & $0.44 \%$ \\
P25 & 5717 & 396 & 5629 & $-1.54 \%$ \\
P26 & 5992 & 430 & 5833 & $-2.66 \%$ \\
P27 & 5705 & 425 & 5802 & $1.70 \%$ \\
P28 & 5717 & 421 & 5779 & $1.08 \%$ \\
P29 & 5706 & 455 & 5982 & $4.84 \%$ \\
P20 & 5688 & 429 & 5826 & $2.43 \%$ \\
\hline
\end{tabular}


that quantity of base grout increases linearly with positive upward slope (Fig. 3). Base grout quantity has been determined varying diameter of pile and length of pile for fix deposition sediment thickness of $500 \mathrm{~mm}$ and presented graphically (Fig. 4). It is observed that quantity of base grout increases linearly with positive upward slope (Fig. 4). Similar graphs can be developed for $300 \mathrm{~mm}, 500 \mathrm{~mm}$ and $700 \mathrm{~mm}$ etc. deposition of sediment.

\section{Conclusions}

In the absence of a suitable proven model and / or a method, the proposed model can be used for the determination of base grout quantity and may be used in the feasibility / detailed design stage for quantity estimation and then supervision stage for execution of work. The proposed model has been validated and found to bear satisfactory results.

Depth of sediment is the most important factor for estimation of quantity of base grout. Base grout quantity depends on the extent of deposition allowed. Following conclusions are also drawn from present study:

- Base grout quantity varies linearly upward with positive slope with fixed deposition of sediment when length of pile and diameter of pile are varied.

- Base grout quantity varies linearly upward with positive slope with fixed pile length when deposition of sediment and diameter of pile are varied.

- Base grout quantity varies linearly upward with positive slope with fixed pile diameter when deposition of sediment and length of pile are varied.

Abbreviations

TAM: Tube a Manchette; MPa: Mega Pascal

\section{Acknowledgements}

We are thankful to ICT Management to allow us for the preparation of the document and the Project Implementation Unit, Paira Bridge Construction, Roads and Highways Department, Government of Bangladesh.

Data share

No objection for data sharing.

Authors' contributions

S K BAGUI: Main Author-Collection of field data, literature review, preparation of document. S K PURI: Guide team member for document, cost variation of project, estimation of base grout quantity. VENKAT RAO: Methodology for base grout, preparation of scheme. B C Dinesh: Field Implementation, spacing of TAM, TAM Size, Base Grouting pipe dia finalisation etc. ATASI DAS: Overall monitoring, collection of document and finalisation of the technical paper. The authors read and approved the final manuscript.

Funding

No research funding is available.

Competing interests

The authors declare that they have no competing interests.

Author details

${ }^{1}$ CGM, HOD (PMG Division) ICT (I) Pvt. Ltd, New Delhi, India. ${ }^{2}$ ICT (I) Pvt. Ltd, A 8 Green Park, New Delhi, India. ${ }^{3}$ G R Infra Limited Gurgaon, Sector 18, Gurgaon, India.

Received: 31 January 2020 Accepted: 26 May 2020

Published online: 07 July 2020

References

Bolognesi AJL, Moretto O (1973) Stage grouting preloading of large piles on sand. Proceedings of 8th ICSME, Moscow Bruce DA (1986) Enhancing the performance of large diameter piles by grouting. Parts 1 and 2, Ground Eng 19(4):9-15 and 19(5), pp. 1121-1126

Chu Eu Ho (2012). Base Grouted Bored Pile on Weak Granite Grouting and Ground Treatment (716 - 727), Third International Conference on Grouting and Ground Treatment February 10-12, 2012, New Orleans, Louisiana, United States 
Dapp SD, Muchard M, Brown DA (2006) Experience with base grouted drilled shafts in the southeastern united state. Proceedings of 10th international conference on piling and deep foundations, Deep foundations institute, Amsterdam article \#1385, publication \#77 (IC-2006)

Endicott $L$ (1980) Aspects of design of underground railway structures to suit local soil conditions in Hong Kong. Hong Kong Engineer 8(3):29-38

Evans GL, McNicholl DP, Leung KW (1982) Testing in hand dug caissons. Proc Seventh Southeast Asian Geotech Conference, Hong Kong 1:317-332

Gouvenot D, Gabiax FD (1975) A new foundation technique using piles sealed by concrete under high pressure. In: Proceedings, Seventh Annual Offshore Technical Conference, HoustonVol. 2, Paper No. OTC 2310, pp 641-656

Liao H-J, Su S-F (2012) Base Stability of Grout Pile-Reinforced Excavations in Soft Clay. J Geotechand Geoenviron Eng ASCE 138(2):184-192

Mullins G, Dapp S, Fredreric E, Wagner R (2001) Pressure grouting drilled shaft tips - phase I. In: Final report submitted Florida Department of Transportation, Florida

Mullins G, Winters D, Dapp S (2006) Predicting end bearing capacity of post-grouted drilled shaft in cohesionless soils. ASCE-GI J Geotech Geoenviron Eng 132(4):478-487

Sinnreich AJ, Simpson RC (2015) Case histories of full-scale comparative load testing of base grouted and Ungrouted test shaft pairs. In: Proceedings of the international foundations congress and equipment expo 2015, San Antonio, pp 486-499

Stocker M (1983) Influence of post-grouting on the load-bearing capacity of bored piles. In: Balkema AA (ed) Proceedings of the European conference on soil mechanics and foundation engineering, Helsinki, pp 167-170

Wang WD, Wu JB, Di GE (2006) Performance of base grouted bored piles in specially big excavation constructed using topdown method. Geo Shanghai International Conference 2006 June 6-8, 2006, Shanghai

Zhang Z, Lu T, Zhao Y, Wang J (2004) Pile-bottom grouting Technology for Bored Cast-in-Situ Pile Foundation. GeoSupport Conference 2004:935-944

Zhihui W, Dai G, Gong W, Rizvi F (2016) Research on the Load Settlement Relationship of Post-Grouted Based on the Load Transfer Function Method on Yueqing Bay Bridge. In: 11th Asia Pacific Transportation Development Conference and 29th ICTPA Annual Conference.

\section{Publisher's Note}

Springer Nature remains neutral with regard to jurisdictional claims in published maps and institutional affiliations.

\section{Submit your manuscript to a SpringerOpen ${ }^{\circ}$ journal and benefit from:}

- Convenient online submission

- Rigorous peer review

- Open access: articles freely available online

- High visibility within the field

Retaining the copyright to your article

Submit your next manuscript at $\boldsymbol{\sim}$ springeropen.com 